\title{
Understanding of Tritium Behavior Toward Sediment in Aquatic System
}

\author{
M. Ari Saputra ${ }^{1,2,3}$, Mireille Del Nero ${ }^{3}$, Quaranta Gaetana ${ }^{3}$, Olivier Cours on ${ }^{3}$ \\ \{m.ari.s@mail.ugm.ac.id, mireille.delnero@iphc.cnrs.fr, quaranta@unistra.fr, \\ olivier.courson@iphc.cnrs.fr\}
}

\author{
Universitas Gadjah Mada, Bulaksumur, Daerah Istimewa Yogyakarta 55281, Indonesia ${ }^{1}$, \\ IMT Atlantique Nantes Campus, La Chanterie 4, rue Alfred Kastler, 44307, Nantes, France ${ }^{2}$, \\ Université de Strasbourg, CNRS, Institut Pluridisciplinaire Hubert Curien (IPHC), UMR7178, F-67000 \\ Strasbourg, France ${ }^{3}$
}

\begin{abstract}
Tritium is one of the hydrogen isotopes and can be produced either by a cosmic ray or human activities such as waste from nuclear facilities and chemical industries. Recent studies have shown that tritium can be bounded with organic matter and possibly with nanoparticles in aquatic systems. This form of tritium known as organically bound tritium can be trapped in sediment and lead to the potential of ecotoxicity. This paper will give insight how the tritium can be absorbed by modeled sediment and can be further absorbed with help of organic matter present in the system.
\end{abstract}

Keywords: Ecotoxicity, Organically bound tritium, Tritium.

\section{INTRODUCTION}

Tritium is one of the hydrogen isotopes and can be produced either by a cosmic ray or human activities. When neutron from cosmic radiation interacts with nitrogen, nitrogen-15, which is radioactive, is produced and disintegrates into carbon and tritium. This tritium will reside in the atmosphere in a gaseous form (HT) and as water vapor (HTO). Tritium also can be produced from nuclear facilities such as nuclear power plant (NPP) and nuclear reprocessing facility [1], [2]. Some chemical industry also can release a little amount of tritium in the environment. This tritium is called "technogenic" tritium because it is mainly released by pharmaceutical industries, in luminous paint residues by the watch industry, or with residues by factories manufacturing luminous safety lighting [3].

The nuclear power plant is the main producing of tritium. Intemational Atomic Energy Agency (IAEA) reports showing that one nuclear power plant facility can release 11 to 27 $\mathrm{TBq} / \mathrm{year}$ tritium in liquid form and 0.2 to $0.8 \mathrm{TBq} / \mathrm{year}$ tritium in gas eous form depends on types of the reactors [4]. In the environment, it can exist as tritiated water (HTO) and organically bound tritium(OBT). Growing amounts of studies on the environmental behavior of tritium indicate different behaviors dependent on chemical speciation (OBT, $\mathrm{NE}$ (non-exchangeable)-OBT, HTO) as shown in the study of Rhone river, France. Latest research has shown that tritium in OBT form can be trapped in the sediment and reside in water [1], [3], [5]-[7]. The tritium trapped in sediment has long period biological time, which can lead to an aquatic ecotoxicity potential.

It has thus been found that the influence of a nuclear facility or possibly chemical industry on tritium levels is expressed at a local scale and is visible in the aquatic environment. This study is aiming to get an understanding of tritiumbehavior in the aquatic system. 


\section{TRITIUM FORM IN ENVIRONMENT}

In the environment, because tritium is an isotope of hydrogen, tritium is present in all part of the geosphere, including the atmosphere, hydrosphere and lithosphere, the biosphere and the anthroposphere. It is also present in many physical and chemical forms.

\section{A. Tritiated Water $(\mathrm{HTO})$}

Tritiated water(HTO) is the most common formof tritium in the geochemical systems and in living organisms. This form can be found throughout the whole hydrosphere cycle in the environment. It is very mobile since it has similarity with normal water. HTO concentration in hydrosphere depends on many factors such as latitude, seas on, the age of the water mass, hydrology, drainage basin size, precipitation rate of minerals, and altitude. [3].

The mean concentration of HTO in French river water $(1,4 \mathrm{~Bq} / \mathrm{L})$ is the same with HTO concentration in rainwater $(1,6 \mathrm{~Bq} / \mathrm{L})$ due to radioactive decay during the mass transfer from atmosphere to hydrosphere [5]. The concentration of HTO is varying because of a rapid transfer of hydrogen and water molecules with different components in the environment. HTO can also be found in the atmosphere in the form of water vapor.

\section{B. Organic Bound Tritium $(O B T)$}

Inorganically bound tritium can be linked either by covalent bound or weak hydrogen bond. Organically Bound Tritium (OBT) initially integ rates org anic matter cycle mainly during the photosynthes is process. Thus it will move to the biosphere through the food chain. Many research has been done to investigate OBT in the environment. Because tritium is part of the organic matter cycle, OBT is accumulated in organic matter storage media, especially in the sediments of streams and rivers. [6]. Tritium can persist in both terrestrial and aquatic environments according to the recycling rates of organic matter. A study showed that the mean Organically Bound Tritium (OBT) concentration in the sediments of Rhone river in France, is not significantly different from the mean HTO concentration recorded for rainwater $(2.4 \pm 0.6$ $\mathrm{Bq} / \mathrm{L}$ and $1.6 \pm 0.4 \mathrm{~Bq} / \mathrm{L}$, respectively) [8]. The authors have the hypothes is that regional differences are expected depending on the biomass inventories affected by the global fallout and the recycling rates of the organic matter in the various affected watersheds. Hence, there are possibilities that seasonal factors also affect OBT concentration.

Several studies have been done on the behavior of tritium in the aquatic sys tems. Tritium behavior in aquatic systems is influenced by its various forms and biogeochemical exchanges among aquatic components, as can be shown in Figure 2. Tritium is bound to dissolve, colloidal or particulate organic compounds either through exchange reactions or enzymatically catalyzed reactions. In exchange reactions, tritium is bound to oxygen, sulfur, phosphorus or nitrogen atoms through weakhydrogen bonds, resulting in forms that are more or less exchangeable with ambient oxide hydrides known as Exchangeable Organically Bound Tritium (E-OBT). In the case of enzymatically catalyzed reactions, tritium is bound to carbon atoms and is permanently fixed to the resulting molecules until they are metabolized. Such forms are referred to as Non-Exchangeable Organically Bound Tritium(NE-OBT). [9] 


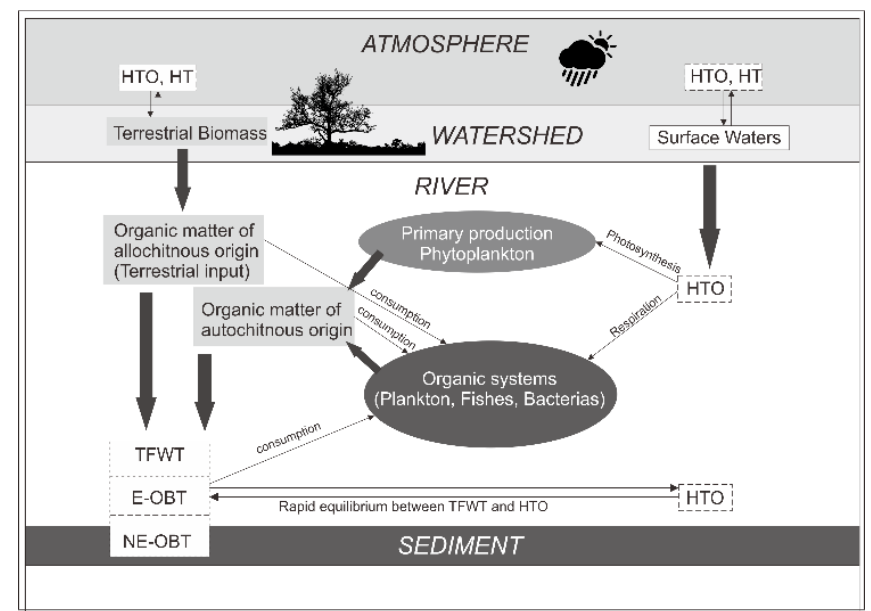

Fig. 1. Tritium behavior in aquatic system. (1) NE-OBT will become E-OBT through biodegradation of organic matter after a long time of retention. [9]

E-OBT is tritium bound with sulfur, oxygen, or nitrogen atoms and can be removed by washing with Tissue Free Water Tritium (TFWT). E-OBT equilibrates very quickly with TFWT, which is itself at equilibrium with the water molecules in the surrounding environment [1], [3]. Also, E-OBT is in equilibrium with HTO in the plant or animal and behaves the same as HTO. This fraction of OBT depends strongly on the HTO concentration present at the time of sampling and can exchange with water vapor during analysis. [1].

NE-OBT is tritium covalently bond with carbon atoms, and it makes stronger bound than tritium bound in E-OBT. Unlike E-OBT, tritium in this form has a biological period that depends on the molecules on which it is bound. If the tritium is bound with fast metabolism species of org anic mattersuch as carbohydrates, it can stay in this form from few weeks and few months until it degrades. On the otherhand, tritium can be bound with slow metabolism species of org anic matter, and in this form, tritium can be bound for several years or decades. [3], [6].

Recent studies have shown that NE-OBT causes tritium to persist in organic matter and that the fate of NE-OBT depends on the reaction kinetics, particularly the decomposition and recycling dynamics of the organic compounds. Higher OBT concentrations than the HTO concentrations of the surrounding environment have been widely observed in terrestrial plants and river sediments collected away from the influence of releases from nuclear facilities. For example, OBT concentration observed in the Loire river ranges from 10 to $23 \mathrm{~Bq} / \mathrm{L}$, and the HTO concentration ranges from 6.9 to $21 \mathrm{~Bq} / \mathrm{L}$ [7]. This shows the persistence of tritium initially integrated into the org anic matter within these matrices. [1], [3], [5], [6]. Another study in Qinshan Nuclear Power Plant, China, showed that for soils collected at $\pm 2 \mathrm{~km}$ from the nuclear power plant, there is a correlation between NE-OBT and HTO ratio in soil samples. They concluded that this could happen because of living organis m converting HTO into OBT. [10]. This indicates that NE-OBT exists in an environment not only because of organic matter but als o because of living organism. 


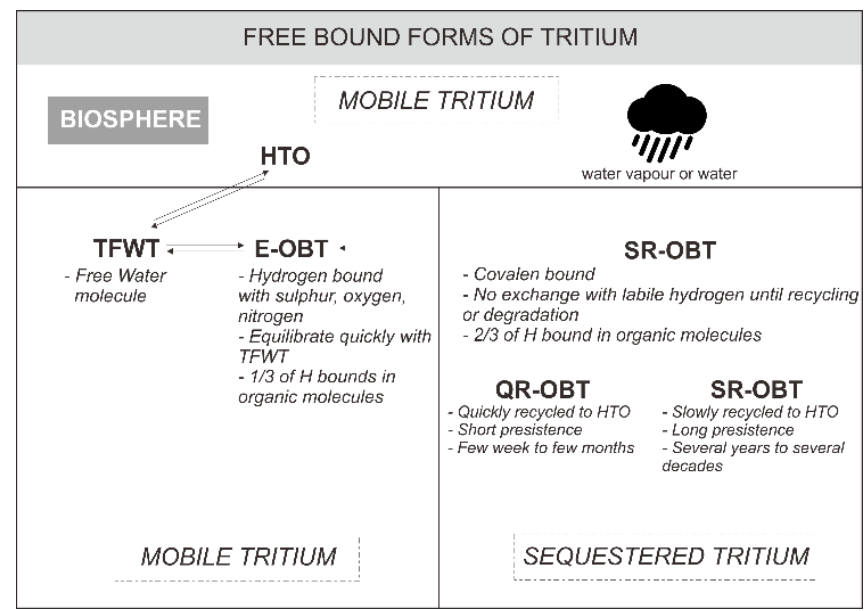

Fig. 2. Tritium form in the environment [3]

As noted before, tritium in NE-OBT can cause resistance for several years. It o can be bound with many types of organic carbon, and there is a possibility that tritium can be bound in close association with organic molecules sorbed at surfaces of nanoparticles. Also, research showed that around $70 \%$ of the tritium bound to the organic matter is in a non-exchangeable form, and the other $30 \%$ is tritium is bound with org anic matter as E-OBT [3].

\section{MATERIALS AND METHOdS}

\section{A. Sample Location}

The experiment of tritium adsorption on the sediment was done with extracted organic matter and pre-treated sediment from the Rhine river, located in eas tern France. The river is near many industries area including nuclear power plant, chemichal industries, and agriculture area. $300 \mathrm{~g}$ sediment was taken in the Rhine river bank (the sample point can be shown in figure 3) with depth $\pm 5 \mathrm{~cm}$ from ground surface. The collected sediment was putted in $500 \mathrm{ml}$ plastic bottle and then stored in refrigerator with temperature $5^{\circ} \mathrm{C}[8]$.

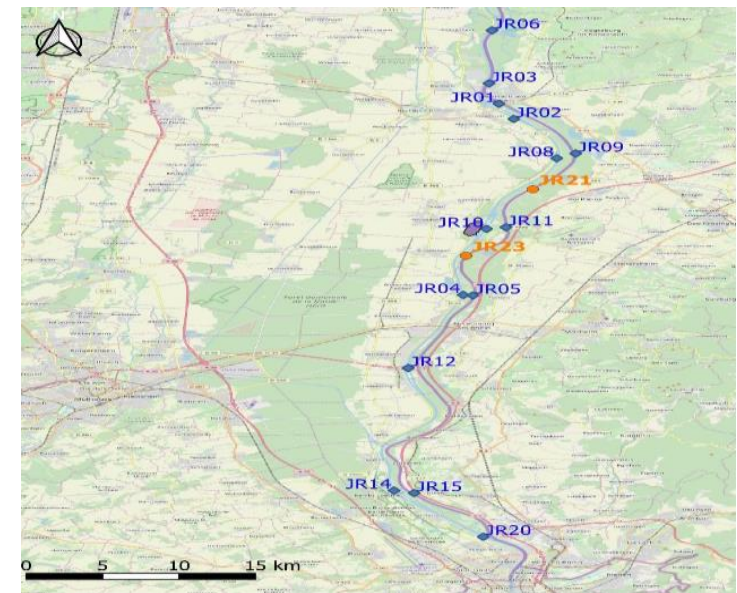

Fig. 3. Location of sediment sample, sample was taken in point JR23 


\section{B. Sample Processing and Measurement}

The sediment collected in the Rhine river was washed three-times using water to remove free tritium. After that, the organic matter was removed using hydrogen peroxide. Then, the model sediment obtained was dried for 6 hours to remove excess water. The sediment without the organic matter was used for two experiments with tritium. The model sediment was used to make two experiments : the first experiment consisted in a $15 \mathrm{~mL}$ solution in contact with $20 \mathrm{mg}$ model sediment only, and the second cons is ted in a $15 \mathrm{~mL}$ solution with $20 \mathrm{mg}$ model sediment and $302 \mu \mathrm{L}$ extracted organic matter from the Rhine river system (the organic matter reconcentrated at a value $623.3 \mathrm{mgC} / \mathrm{L}$ ). The solution $\mathrm{pH}$ was adjusted around 6.5 to 7.5 as measured in the Rhine river system. These two solutions added $10 \mu \mathrm{L}$ tritium standard with a known concentration $(74.1 \mathrm{~Bq} / \mathrm{L}$ ) and then (after shaking during two hours and sediment-solution separation) the supematants were measured with Liquid Scintillation Counting (LSC). The LSC used for meassurement is Perkin-Elmer QUANTULUS Ultra Low Level Liquid Scintillation Spectrometer.

Table 1. Performance data of QUANT ULUS Ultra Low Level Liquid Scintillation Spectrometer.

\begin{tabular}{|c|c|c|}
\hline Isotopes & Efficiency & Background \\
\hline${ }^{\mathrm{J}} \mathrm{H}$ & $\begin{array}{l}\text { - Unquenched }{ }^{5} \mathrm{H} \geq \\
65 \% \text {. } \\
\text { - Water Sample } \\
\text { Efficiency up to } \\
27 \% \text {. }\end{array}$ & $\begin{array}{l}\text { - } 0.4-1.2 \mathrm{CPM} \text {. } \\
500 \text { min counting. }\end{array}$ \\
\hline${ }^{14} \mathrm{C}$ & $\begin{array}{l}\text { - Unquenched }{ }^{3} \mathrm{H} \geq \\
95 \% \text {. } \\
\text { - Radiocarbon } \\
\text { dating with PAC } \\
=73 \% \text {. }\end{array}$ & - <0.3 СРM. \\
\hline
\end{tabular}

To determine tritium concentration, $8 \mathrm{~mL}$ of water samples were mixed with $15 \mathrm{ml}$ high-efficiency LSC cocktail (Perkin-Elmer 'Ultima Gold LLT') then the samples were measured with LSC to count the activities of tritium in water samples. The counting time was $7200 \mathrm{~s}$ and three-time measurements were done for each sample. The measurement efficiency $\varepsilon$ was determined by inner standard source method.

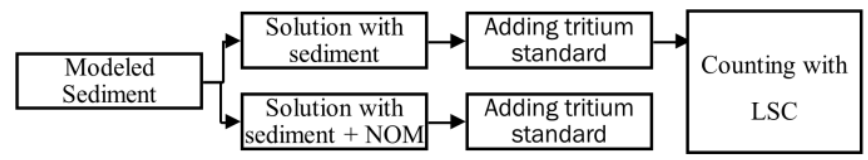

Fig. 4. Scheme of tritium adsorption experiment

The experiment is aiming to see the adsomtion of tritium from the Rhine river sediment sample and to reveal whether the organic matter may affect tritium adsorption on the sediment.

\section{RESULTS AND DISCUSSION}

The experiment used the "model sediment" sample (sediment from which organic matter was removed) and organic matter extracted from the water of the Rhine River (and reconcentrated at a value of $623.3 \mathrm{mgC} / \mathrm{L}$ after extraction). $20 \mathrm{mg}$ of sediment sample was 
brought in contact with $15 \mathrm{ml}$ solution. One of the solutions was added $302 \mu \mathrm{L}$ of extracted organic matter solution. The ratio between sediment sediment and organic matter in the solution was $9.06 \mathrm{mgC} / \mathrm{g}$ sediment. Both solution then added $0.0196 \mathrm{~g}$ of tritium standard for solution without organic matter and $0.021 \mathrm{~g}$ of tritium standard for solution with organic matter. These tritium standard has activities $0.235 \mathrm{~Bq}$ and $0.169 \mathrm{~Bq}$, respectively. After shaking and separation, the supernatant solution was measured by LSC to see is there any difference in tritium concentration. The res ult of the experiment can be shown in Table 2.

Table 2. Tritium adsorption result

\begin{tabular}{|c|c|c|c|c|c|c|}
\hline Solution & $\begin{array}{c}\text { Mass } \\
\text { of }{ }^{3} H \\
\text { added } \\
(\mathrm{g})\end{array}$ & $\begin{array}{c}\text { NOM } \\
\text { added } \\
(\mu \mathrm{L})\end{array}$ & $\begin{array}{c}\text { Mass of } \\
\text { sediment } \\
\text { added } \\
(\mathrm{mg})\end{array}$ & $\begin{array}{c}{ }^{5} \mathbf{H} \\
\text { Meassured } \\
(\mathrm{Bq} / \mathrm{L})\end{array}$ & $\begin{array}{c}{ }^{3} \mathbf{H} \\
\text { Activities } \\
\text { (B q) }\end{array}$ & $\begin{array}{c}\text { Adsor } \\
\text { ption } \\
(\%)\end{array}$ \\
\hline Sediment & 0.0196 & - & 21 & 15.7 & 0.235 & 80 \\
\hline $\begin{array}{l}\text { Sediment } \\
+\mathrm{OM}\end{array}$ & 0.021 & 302 & 20 & 11.3 & 0.169 & 86 \\
\hline
\end{tabular}

The results indicated that the tritium was absorbed by "model sediment" as much $80 \%$. When the natural org anic matter was present in the sample, the adsorption increased to $86 \%$. To know the sediment characters, Trans mission Electron Microscopy (TEM) was done. The TEM analys is can see particles that present on the sediment and predict what elements that are in the particles. The TEM imaging results showed that several types of nanoparticles were present in the sediment sample. The majority of the nanoparticles present are calcite $\left(\mathrm{CaCO}_{3}\right)$, and clay nanoparticle possibly as smectites (containing iron). The particle sizes vary from $10 \mathrm{~nm}$ up to 1 $\mu \mathrm{m}$, which indicates there are many groups of calcite and smectite in the sample. Figure 5 showed that pictures of nanoparticles that can be found in the sample. The left picture is nanoparticle of clay nanoparticle present in the sample with the size of $\pm 1 \mu \mathrm{m}$. The big particle was identified as a clay material consist of aluminum, silica, and iron. The right side picture shows calcite nanoparticle with the size of $\pm 5 \mu$ m present on the edge of particle with size of 20 $\mathrm{nm}$. The picture also indicated there are many groups of nanoparticle with different size. We know that surface of smectite bear hydroxyl groups $(\mathrm{OH})$ so that there may be isotopic exchange between thehydrogen of the surface hydroxyls and tritium[11].

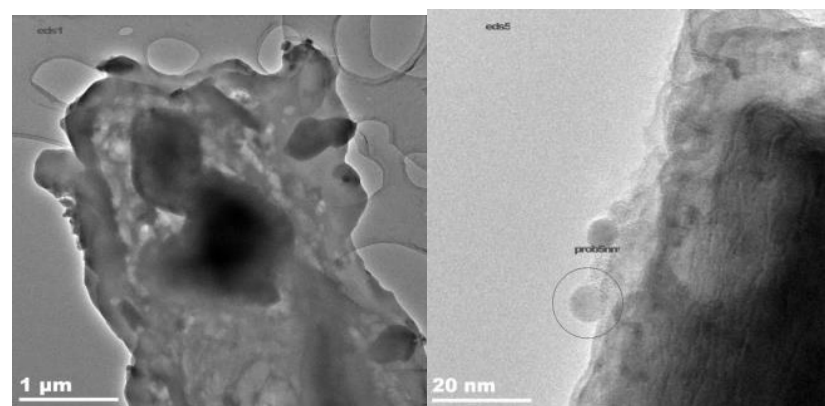

Fig. 5. Different size of nanoparticle present on the sample; nanoparticle of clay mineral (left) and calcite (right)

From TEM analysis, it is known that in the sample we have the presence of smectite. The adsorption of tritium in the sediment might be because of smectite present in the sediment as a nanoparticle or bigger mineral. The smectite can absorb the tritium because of the hydroxyl 
group in the surface of smectite have is otopic exchange with the tritium in the solution. The result also indicates the organic matter helps to increase sediment tritium adsorption. The organic matter can help the adsorption of tritium possibly because organic matter is adsorbed on the surface of the sediment and organic matter adsorb tritium directly. This result suggests that, besides its association with suspended nanoparticles, tritium is expected to be bound to sediment -and organic sorbed to the sediment s ample.

\section{CONCLUS ION}

The sample collected from the Rhine River system showed that there are pres ent of calcite and smectite nanoparticle. The experiment showed that tritiumcan be absorbed by sediment, the absorption might be happened due to presence of smectite nanoparticle and possibly with calcite. In addition, the presence of organic matter in the system can help tritium adsorption to sediment. The adsomtion of tritium in sediment might be different depends on the characteris tics of the sediment. In this case, sediment with the majority cons ist of smectite can abs orb tritium.

\section{REFERENCES}

[1] S. B. Kim, N. Baglan, and P. A. Davis, "Current understanding of organically bound tritium (OBT) in the environment," J. Environ. Radioact., vol. 126, pp. 83-91, 2013.

[2] E. Mazor, Chemical and Isotopic Groundwater Hydrology, Vol.98. 2003.

[3] F. Eyrolle et al., "An updated review on tritium in the environment," J. Environ. Radioact., vol. 181, no. September 2017, pp. 128-137, 2018.

[4] IAEA, "REJETS DE TRITIUM ET IMPACT AUTOUR DES CNPE D' EDF Bernard Le Guen, Vincent Chrétien, Pierre-Yves Hémidy, Marie-Joseph Sago t," 2007.

[5] L. Ducros et al., "Science of the Total Environment Tritium in river waters from French Mediterranean catchments : Background levels and variability," Sci. Total Environ., vol. 612, pp. 672682, 2018.

[6] F. Eyrolle et al., "Science of the Total Environment A brief history of origins and contents of Organically Bound Tritium ( OBT) and $14 \mathrm{C}$ in the sediments of the Rhône watershed," Sci. Total Environ., vol. 643, pp. 40-51, 2018.

[7] O. Péron, C. Gégout, B. Reeves, G. Rousseau, G. Montavon, and C. Landesman, "Anthropogenic tritium in the Loire River estuary, France," J. Sea Res., vol. 118, pp. 69-76, 2016.

[8] F. Eyrolle-Boyer et al., "Tritium and 14C background levels in pristine aquatic systems and their potential sources of va riability," J. Environ. Radioact., vol. 139, pp. 24-32, 2015.

[9] C. Cossonnet, "Apparent enrichment of organically bound tritium in rivers explained by the heritage of our past d e Fre," vol. 136, pp. 162-168, 2014.

[10] Q. Zhang et al., "Studies of particle size distribution of Non-Exchangeable Organically Bound Tritium activities in the soil around Qinshan Nuclear Power Plant," J. Environ. Radioact., vol. 192, no. November 2017, pp. 362-367, 2018.

[11] A. Kuligiewicz, A. Derkowski, J. Środoń, V. Gionis, and G. D. Chryssikos, "The charge of wettable illite-smectite surfaces measured with the O-D method," Appl. Clay Sci., vol. 161, pp. 354-363, Sep. 2018. 